Bond University ePublications@bond

Sports Law eJournal

Faculty of Law

$7-1-2005$

\title{
When, where and why does the State intervene in Sport : a contemporary perspective
}

Anneliese Nelson

Follow this and additional works at: http://epublications.bond.edu.au/slej

Part of the Entertainment, Arts, and Sports Law Commons

\section{Recommended Citation}

Anneliese Nelson. (2005) "When, where and why does the State intervene in Sport : a contemporary perspective" , .

http://epublications.bond.edu.au/slej/1 


\title{
When, where and why does the State intervene in Sport : a contemporary perspective
}

\begin{abstract}
[Extract] On Friday 19 November 2004, a violent brawl broke out on the basketball courts of Auburn Hills, Michigan, USA.1 It occurred in the final minute of a game between the Detroit Pistons and the Indiana Pacers at national level. The fight between the players was taken into the stands after one spectator threw water over a player. Bottles, chairs and other debris were thrown onto the courts. The offending players were suspended indefinitely. Furthermore, the police considered pressing criminal charges, primarily because the fight involved spectators. On the playing field this sort of behaviour is of regular occurrence and is usually accepted. A government rarely steps in to charge a player with assault or battery following a violent brawl during a game. Hence, it has been said that this event could be a watershed in American sport; one which could change the way players interact in the future. However, sport is afforded special treatment by both society and the State. One wonders how an isolated event such as this could affect a well established lenient approach designed to accommodate sporting pastimes.
\end{abstract}

\section{Keywords}

sport, government

\section{Disciplines}

Entertainment, Arts, and Sports Law 


\section{When, Where and Why does the State Intervene in Sport? A Contemporary Perspective}

\section{By Anneliese Nelson}

Date of publication 1 July 2005

\section{INTRODUCTION}

On Friday 19 November 2004, a violent brawl broke out on the basketball courts of Auburn Hills, Michigan, USA. ${ }^{1}$ It occurred in the final minute of a game between the Detroit Pistons and the Indiana Pacers at national level. The fight between the players was taken into the stands after one spectator threw water over a player. Bottles, chairs and other debris were thrown onto the courts. The offending players were suspended indefinitely. Furthermore, the police considered pressing criminal charges, primarily because the fight involved spectators. On the playing field this sort of behaviour is of regular occurrence and is usually accepted. A government rarely steps in to charge a player with assault or battery following a violent brawl during a game. Hence, it has been said that this event could be a watershed in American sport; one which could change the way players interact in the future. ${ }^{2}$ However, sport is afforded special treatment by both society and the State. One wonders how an isolated event such as this could affect a well established lenient approach designed to accommodate sporting pastimes.

Societal opinion, culture and national pride have always driven state control over sport. Today, sport is a “circus for the masses." Most of humanity is uplifted when viewing their favourite team or partaking in the sport of their choice in their free time. The State has a careful balance to maintain between regulating for protection of the public while recognising the value of choice in increasingly liberal societies.

\footnotetext{
${ }^{1}$ AFP, 'Four Out After Players Brawl with Fans’ Monday 22 November, 2004 Sydney Morning Herald at 23.

2 S Springer, 'NBA Humiliated by Brawling Players, Fans' The Australian, Monday 22 November 2004, 20.
} 
State involvement in sport is haphazard and piecemeal. There are five main ways the State regulates sport. Firstly, the taxation of sports people ${ }^{3}$ and sporting entities is firmly legislated. Second, some jurisdictions have legislation governing particular sports such as boxing. Many have strong regulation on drug use in sport. Third, wagering and betting statutes affect all types of sports with which gambling is associated. Fourth, the State encourages sport through funding, various fitness regimes and public health initiatives usually put forward by Health Departments. Lastly, there are some circumstances where the criminal law is invoked. This is largely to make a spectacle of particularly dangerous or callous behaviour on the sporting field and is by no means consistently applied. Furthermore, the criminal law is used in the sporting context to protect and uphold one of the main functions of government: prevention of breaches of the peace.

Violence has played a large role in sport throughout the ages. For example, the Romans sought entertainment through the slaughter of humans and animals in the Colosseum. While it is true that the degree of violence in sport has diminished over time, it is still afforded a special tolerance. If one strikes someone's head with a hard object, this provides grounds for battery, or even attempted murder. The occurrence of the same act during an ice hockey match is sometimes accepted. If a player punches an opponent repeatedly during a rugby match resulting in a broken nose, the player may be sent off the field. At worst, they may be suspended from play for a period of time by a disciplinary board. If this same act was to occur on the street, the perpetrator would be arrested for assault occasioning bodily harm or even grievous bodily harm.

So, why is it that acts on the sporting field are treated so differently? Should the law have a special tolerance for sport? Firstly, this article seeks to address these questions in relation to the areas of sport where legislation has been invoked. Second, the common law approach to violence in sport is considered.

\section{CURRENT Regulation OF SPORT}

In all jurisdictions, regulation of sport occurs on five levels:

\footnotetext{
${ }^{3}$ See, eg, Stone v Commissioner of Taxation [2003] FCAFC 145 and TR1999/17: Income Tax: Sportspeople - Receipts and Other Benefits Obtained From Involvement in Sport.
} 
1. The formulation of the rules of the game;

2. The application of immediate sanctions during the course of the game should a breach of the rules occur;

3. Disciplinary proceedings performed by administrative bodies who punish those who contravene the rules and provide an opportunity for review of decisions; ${ }^{4}$ and

4. Intervention by State or Federal Governments when a participant's behaviour infringes the criminal law or a civil action is brought.

5. International committees such as the International Olympic Committee or the Court of Arbitration for Sport are used to resolve disputes.

The following discussion is concerned with item four as well as the enactment of legislation by the State to control certain sporting activities. There is very little sport-specific legislation.

\section{A Boxing and Combat Sports}

Common law countries see boxing as an exception to the general law. Despite that the object of the sport is to render blows that may see the opponent incapable of defending him or herself, laws such as assault, battery and murder are not necessarily applied.

The majority of the House of Lords in the highly influential English case of $R v$ Coney ${ }^{5}$ viewed unregulated prize fights as threatening to the public interest in the maintenance of good order. A similar view of sparring was taken. Thus, when the legality of boxing is in issue at common law, the outcome is completely dependent on whether or not the evidence makes out that the activity is either prize fighting or sparring. ${ }^{6}$ The Law Commission Consultation Paper No 134, entitled "Consent and Offences against the Person", suggested that the exemption of boxing from the criminal law is, "so firmly embedded in the law that only special legislation can change the position.”7 This is so, even though the sport results in serious injury or death in a significant number of cases. However, the writers chose not to suggest whether or not such legislation should be enacted for two reasons. Firstly, boxing is an anomaly when compared to the

\footnotetext{
${ }^{4}$ Craig Moore, Sports Law and Litigation (2 ${ }^{\text {nd }}$ ed, 2000) 9.

5 (1882) 8 QBD 534 (CCR).

${ }_{7}^{6}$ Edward Grayson, Sport and the Law (2 ${ }^{\text {nd }}$ ed, 1998) 70.

${ }^{7}$ Ibid 70 .
} 
rules of other sports and games, and second, the issue is highly debatable and cannot be solved by any appeal to the common law. ${ }^{8}$ Thus, there is no legislation in the United Kingdom devoted to the regulation of boxing, martial arts or other combat sports. It is the judiciary who must determine the legality of individual actions with little guidance from Parliament.

In Canada, boxing is exempt from the provisions of the Criminal Code. ${ }^{9}$ This is recognition of the authority of the individual Provinces to control the sport. For example, under the Athletes Control Act ${ }^{10}$ of Ontario, the Athletics Commissioner has the power to regulate and license professional boxing. This authority also includes the regulation of amateur boxing and wrestling under provincial sports organisations. ${ }^{11}$ It is at the amateur level that the competitions are uniform, with bouts limited to three rounds only. Thus, knock-outs are rare. ${ }^{12}$ Legislation in Canada is not uniform in the provision of age limitation for amateur boxing. In a report by the Canadian Amateur Boxing Association, ${ }^{13}$ a strict adherence to a minimum age of 11 years was recommended. This was despite the fact that many consider this to be an age where the child is still too young to make an informed choice regarding participation in a sport where the risk of harm is significant. ${ }^{14}$

The Australian position is similar to that of Canada and the United Kingdom in that boxing is exempt from the relevant criminal codes ${ }^{15}$ and left to the individual states to regulate. However, boxing is not regulated in Queensland, Tasmania or the Northern Territory. The criminal law does provide prohibitions of both prize fighting and duelling in Queensland for example. ${ }^{16}$

\footnotetext{
${ }^{8}$ Law Commission Consultation Paper No 134 at [10.21-10.22], cited in Edward Grayson, Sport and the Law (2 ${ }^{\text {nd }}$ ed, 1998$) 70$.

${ }^{9}$ R.S.C 1985 s 83(2).

${ }^{10}$ RRO 1990.

${ }^{11}$ John Barnes, Sports and the Law in Canada (3 ${ }^{\text {rd }}$ ed, 1996) 40.

12 Ibid 42.

${ }^{13}$ For Amateur Boxing: The Report of the Amateur Boxing Review Committee (Toronto: Ministry of Tourism and Recreation, 1983) 34-46, cited in John Barnes, Sports and the Law in Canada ( $3^{\text {rd }}$ ed, 1996) 42.

14 John Barnes, ibid 42.

${ }^{15}$ See, eg, the Criminal Code Act 1899 (Qld), Criminal Code Act (NT), Criminal Code Act 1924 (Tas), Crimes Act 1958 (Vic), Criminal Code (WA), Crimes Act 1900 (NSW), Criminal Code 2002 (ACT), Criminal Law Consolidation Act 1935 (SA) and the Criminal Code Act 1995 (Cth).

${ }^{16}$ Criminal Code 1899 (Qld) ss 73 and 74.
} 
The Boxing and Wrestling Control Act ${ }^{17}$ and the Professional Boxing and Combat Sports Act ${ }^{18}$ of New South Wales and Victoria provide significant restrictions on the licensing of contests and the physical requirements of the competitors. ${ }^{19}$ The purpose of these acts is to control professional boxing and professional combat sports, to reduce the risk of malpractice by competitors, promoters and others involved in the administration of the sport, as well as to promote safety. ${ }^{20}$

Those who wish to involve themselves in boxing as a promoter, trainer, match-maker, referee or judge must apply to the Minister for a license. ${ }^{21}$ In Victoria, a penalty of 120 penalty units or twelve months imprisonment are imposed on those who do not comply with the conditions imposed by the Act. ${ }^{22}$ The same penalty applies to a person who aids, abets, counsels or procures the commission of an offence under the Act. $^{23}$

All competitors must be registered to compete. ${ }^{24}$ Under the New South Wales legislation, it is only a male person above the age of 18 years holding a certificate of fitness for boxing who may register. ${ }^{25}$ Competing without registering is an offence and carries 10 penalty units or imprisonment for six months, or both. ${ }^{26}$ The same penalty applies to anyone who engages in sparring, if they are not licensed as a professional boxer. ${ }^{27}$ A professional contestant must be examined by a medical practitioner within 24 hours before, and within 24 hours after, a professional contest, and at any other time the Minister directs in a particular case. $^{28}$

\footnotetext{
171986 (NSW).

181985 (Vic).

${ }^{19}$ See also the Boxing and Martial Arts Act 2000 (SA), Boxing Control Act 1987 (WA) and Boxing Control Act 1923 (ACT) for similar provisions.

${ }^{20}$ See, eg, Professional Boxing and Combat Sports Act 1985 (Vic) s3 - Purpose.

${ }^{21}$ Ibid s 6.

${ }^{22}$ Ibid s 9A.

${ }^{23}$ Ibid s 18.

${ }^{24}$ Ibid s 10.

${ }^{25}$ Boxing and Wrestling Control Act 1986 (NSW) s 8.

${ }^{26}$ Ibid s 15.

${ }^{27}$ See, eg, Boxing and Wrestling Control Act 1986 (NSW) s16.

${ }^{28}$ See, eg, Professional Boxing and Combat Sports Act 1985 (Vic) s12.
} 


\section{Societal Changes in Attitudes to Boxing}

Some critics of boxing have called for greater regulation of the sport and others for total abolition. ${ }^{29}$ These positions have followed both medical evidence proving that blows to the head cause irreparable brain damage, and the incidence of deaths in the ring. Others believe that "a civilised society should not tolerate organised brutality, however brave and heroic it might appear.”30 Several countries such as Sweden, Norway and Iceland have banned the sport all together. ${ }^{31}$

Advocates for the sport contend that it demands skill, agility and creativity. ${ }^{32}$ Leaving arguments in support of the sport aside, it is important to look at the effect of banning sports throughout history. The end result will be that boxing will continue "underground" in an unregulated fashion that is more akin to prize fighting. Rules will not be adhered to and the potential for the incidence of injury or death is increased. Thus, the regulation of such a sport is clearly in the public interest.

\section{B Drugs in Sport}

The twentieth century saw vast technological improvements in sporting equipment, facilities and even new sports. In 1930, steroids were invented by German scientists. Amphetamines were used in cycling and soccer in the 1950s. This was quite apparent at the 1965 Melbourne Summer Olympic Games. The use of particular diets and natural and unnatural herbal concoctions has been common practice in sport since ancient times. However, it went relatively unnoticed until the latter half of the 20th century, ${ }^{33}$ when a cultural change saw the increased use of drugs in general. The development of authoritative systems of testing by governments has been based on faith in science, ${ }^{34}$ as well as the societal opinion condemning the use of drugs in sport.

\footnotetext{
${ }^{29}$ John Barnes, Sports and the Law in Canada (3 $3^{\text {rd }}$ ed, 1996) 41.

${ }^{30}$ Simon Gardiner, Alexandra Felix, Mark James, Roger Welch and John O’Leary, Sports Law (1' ed 1998) 109 citing 'Boxing: That dangerous game', The Guardian, 15 March 1994, 11.

${ }^{31}$ Simon Gardiner, Alexandra Felix, Mark James, Roger Welch and John O’Leary, Sports Law (1 ${ }^{\text {st }}$ ed 1998$) 109$.

32 John Barnes, Sports and the Law in Canada (3 ${ }^{\text {rd }}$ ed, 1996) 41.

33 Antonio Buti and Saul Friedman, Drugs, Sport and the Law (1 $1^{\text {st }}$ ed, 2001) 29.

${ }^{34}$ John Barnes, Sports and the Law in Canada ( $3^{\text {rd }}$ ed, 1996) 87.
} 
The first event that caused the world to wake up to the problem of doping in sport was the death of the Danish cyclist, Knut Jensen at the 1960 Rome Olympic Games. ${ }^{35}$ France and Belgium were the first countries to legislate against the taking of drugs in sport in 1963 and 1964 respectively. In the 1964 Tokyo Summer Olympic Games, the International Olympic Committee (IOC) introduced the first system of testing for stimulants. The motivation for this was both concern for athletes' health and maintenance of ethical standards of play. ${ }^{36}$ It was not until 1971 that the IOC published the first list of banned substances. This included both stimulants and narcotic analgesics. ${ }^{37}$ As time went on, anabolic steroids, testosterone, beta-blockers and diuretics were included in the banned substances list. ${ }^{38}$

Australians became concerned about performance enhancing drugs in the 1980s. The Standing Committee on Environment, Recreation and the Arts investigated the use of such drugs by Australian athletes and the role played by Commonwealth Agencies. The Committee's report of $1990^{39}$ inspired the creation of the Australian Sports Drug Agency ${ }^{40}$ (ASDA). ASDA's role is to collect and test samples from top athletes for the use of substances on the IOC's banned list. It is also to encourage State and Territory governments and organisations to adopt uniform drug testing procedures. ${ }^{41}$ If an athlete tests positive, his or her name is entered onto the Register of Notifiable Events and ASDA will inform the relevant sporting body of the entry. The Australian Sports Commission will also be informed if the athlete is in receipt of government funding. ${ }^{42}$ An athlete may appeal to the Administrative Appeals Tribunal under s 13(6). ${ }^{43}$

The Sydney Olympic Games provided an interesting outcome in relation to enforcement of anti-doping measures. There were over 60 doping cases detected during the games by a new combination of blood and

\footnotetext{
${ }^{35}$ Ibid 30.

${ }^{36}$ Ibid 31.

${ }^{37}$ Ibid 31, citing Senate Standing Committee on Environment, Recreation and the Arts, Drugs in Sport: An Interim Report (Canberra, Australian Government Publishing Service 1989) 82.

${ }^{38}$ Antonio Buti and Saul Friedman, Drugs, Sport and the Law (1 ${ }^{\text {st }}$ ed, 2001) 32.

${ }^{39}$ Senate Standing Committee on Environment, Recreation and the Arts, Drugs in Sport: An Interim Report (Canberra, Australian Government Publishing Service 1989).

${ }^{40}$ Australian Sports Drug Agency Act 1991 (Cth).

${ }^{41}$ Antonio Buti and Saul Fridman, Drugs, Sport and the Law $\left(1^{\text {st }}\right.$ ed, 2001) 41. Victoria is the only State of Australia to have its own drug testing legislation. See the Sports and Drugs Testing Act 1995 (Vic).

42 Antonio Buti and Saul Fridman, Drugs, Sport and the Law (1 $1^{\text {st }}$ ed, 2001) 42.

${ }^{43}$ Australian Sports Drug Agency Act 1991 (Cth).
} 
urine tests. $^{44}$ A number of Chinese athletes withdrew from competition at a late stage. There was speculation that this was a result of their fear of being caught by the testing regime. There were very few world records set during these games. It has been suggested that there may be some correlation between the drug testing and these results. ${ }^{45}$

In Canada, the disqualification of one of its most revered sprinters, Ben Johnson, in the 1988 Seoul Summer Olympics, caused the government to act. The Canadian Centre of Ethics in Sport (CCES) was established in $1991^{46}$ to investigate Ben Johnson's positive test for the anabolic steroid Stanozolol and the general prevalence of doping. ${ }^{47}$ The Canadian legislation features intrusive testing and penalties to deter drug use. This operates alongside general legislation concerned with the "War on Drugs."48 However, as in all jurisdictions, the rationale for regulation of this type is problematic. This is because it involves invasive procedures, thus impacting on the fundamental rights of the individuals concerned. ${ }^{49}$

The Misuse of Drugs Act 1971 is the primary legislation relevant to drug use in the United Kingdom. However, there is no specific legislation regarding drug taking in sport. Responsibility is left up to nongovernmental sporting bodies such as UK Sport who has published a list of banned substances. Testing is run in conjunction with the British Olympic Association. This system is just as effective as in other jurisdictions where specific legislation exists. For example, random testing by the Football Association has resulted in several players being suspended for having recreational drugs in their system. Jason Livingston, a British sprinter, was sent home from the Barcelona Olympics and received a four-year ban from competition. ${ }^{50}$

\footnotetext{
${ }^{44}$ Antonio Buti and Saul Fridman, Drugs, Sport and the Law (1 $1^{\text {st }}$ ed, 2001) 45.

${ }^{45}$ Ibid 46.

${ }^{46}$ Originally known as the Canadian Anti-Doping Organisation, and then the Canadian Centre for Drug-Free Sport.

${ }^{47}$ Canada, Report of the Commission of Inquiry into the Use of Drugs and Banned Practices Intended to Increase Athletic Performance (Ottawa: Minister of Supply and Services, 1990) (Charles L Dubin, Commissioner), cited in John Barnes, Sports and the Law in Canada ( $3^{\text {rd }}$ ed, 1996) 87.

48 John Barnes, Sports and the Law in Canada ( $3^{\text {rd }}$ ed, 1996) 95.

49 Ibid 88.

${ }^{50}$ Edward Grayson, Sport and the Law (2 ${ }^{\text {nd }}$ ed, 1998) 150.
} 
English writer, Gregory Ioannidis, has suggested that the State should impose criminal penalties on the athletes and all those associated with a drug taking event. ${ }^{51}$ The fact that performance enhancing drugs can produce extreme side effects justifies a criminal sanction of grievous bodily harm or even manslaughter. Ioannidis submits that doctors, physiotherapists, trainers, sporting officials and coaches should receive heavier penalties (from three to six years imprisonment). This is because they covered up their illegal actions and chose not to prevent the athlete from taking banned substances. ${ }^{52}$ Despite the extremity of this reaction, if governments are serious about combating the use of drugs in sport as well as in society, this method could be an extremely effective deterrent.

\section{State Justification of Drug Testing}

The $94^{\text {th }}$ Conference of the International Olympic Committee suggested that national governments must apply Anti-Doping legislation in order to combat the wider problem of drug abuse within modern societies. $^{53}$ Most drugs banned by national governments are also illegal under their criminal law. However, others such as diuretics and steroids are not. There are two main policy reasons that governments use to justify legislating in this regard: the health of athletes and the prevention of cheating.

There is much concern for the health and well being of athletes. However, how can State intervention be justified in this respect? Usually this type of regulation is only valid for those who are unable to make an informed choice for themselves, or alternatively, to prevent harm to others. ${ }^{54}$ Many athletes are convinced by their advisers that the only way to succeed is to take performance enhancing drugs. However, this does not mean that their choice is uninformed. In 1992, 198 American athletes were asked whether or not they would take a "magic drug" that would ensure victory in the knowledge that it would kill them five years later. $52 \%$ said they would as winning is so attractive. ${ }^{55}$ In his report, Honourable Charles Dubin CJ

\footnotetext{
${ }^{51}$ Gregory Ioannidis, 'Legal Regulation of Doping in Sport: The Case for the Prosecution’ 11 (2003) Obiter available at $<$ www.lawfile.org.uk> at 10 October 2004, [3].

52 Ibid [15].

${ }^{53}$ Ibid.

${ }^{54}$ Simon Gardiner, Alexandra Felix, Mark James, Roger Welch and John O’Leary, Sports Law (1 $1^{\text {st }}$ ed 1998$) 165$.

${ }^{55}$ Ibid 164, citing Dr B Goldman and Dr R Klatz, Death in the Locker Room 2 (1992, Chicago: Elite Sports Magazine Publications Inc) 23.
} 
stated that "[d]rugs and the unprincipled pursuit of wealth and fame at any cost now threaten our very social fabric."56 Still, one wonders whether the State should have a say in this matter, as it is a personal choice. However, intervention is justified on other grounds concerned with the effect on innocent athletes.

The use of drugs in sport is cheating as it gives a competitor an advantage over others who have not taken drugs. This ethical argument is concerned with upholding the integrity of sport and the reputations of individual athletes. It has been argued that someone born in a snow laden country in Europe will have an advantage over a fellow skiing competitor raised in a country close to the equator. Other physical factors such as the height of basketball players or the greater resources provided to athletes in western countries give rise to a competitive edge. ${ }^{57}$ However, drug use is different as it is an artificial means of getting ahead. It is a breach of the rules of any sport and destroys the purpose of any competition: a test of persons. A level playing field is the only way humans or animals, when pitted against one another, can truly show their strength, motivation, courage and talent.

\section{VIOLENT ACTS IN SPORT}

Violence on the field in sport has been defined as "a physical assault by a player that takes place in a sports context and that is intended to cause physical pain or injury to another player, where such harmful actions bear no direct relationship to the rules and associated competitive goals of the sport." 58 Thus, the key elements of violence in sport are:

\section{1. physical harm;}

2. intention; and

3. non-compliance with the rules of the game.

The first two elements are reflected in the criminal law of countries all over the world. The latter is considered a contributory factor when determining the intention of the player. However, the problem is

\footnotetext{
${ }^{56}$ Canada, Report of the Commission of Inquiry into the Use of Drugs and Banned Practices Intended to Increase Athletic Performance (Ottawa: Minister of Supply and Services, 1990) (The Honourable Charles L Dubin, Commissioner) cited in Edward Grayson, Sport and the Law (2 $2^{\text {nd }}$ ed, 1998) 149.

${ }^{57}$ Simon Gardiner, Alexandra Felix, Mark James, Roger Welch and John O’Leary, Sports Law (1 $1^{\text {st }}$ ed 1998$) 167$.

${ }^{58}$ Canadian Centre for Ethics in Sport, Discussion Paper on Violence in Sport (February 1999), available at $<$ www.cces.ca $>$ at 10 October 2004
} 
that "violent" acts are inherent in some types of sport. In contact sports, the distinction between an injury resulting from "honest play" and one inflicted intentionally with excessive force can be a fine one. ${ }^{59}$ In boxing the object is to assault the opponent. Thus, application of the law of the land is difficult, particularly as there will always be some overlap with the role of sporting bodies.

Very few cases of sporting violence reach the courts. When they do, the prosecution rate is low and any perpetrators who are convicted receive much more lenient sentences than others who commit a similar act in the community. ${ }^{60}$ The famous American case of State $v$ Forbes ${ }^{61}$ resulted in a mistrial. Forbes, a top hockey player, was charged with aggravated assault by use of a dangerous weapon. He jumped on an opponent and punched him repeatedly after striking him with his hockey stick. The hung jury is said to have been influenced by defence counsel's statement that "hockey, not Dave Forbes, should be on trial.”62 Furthermore, on-field violence is rarely prosecuted as opposed to acts committed when the clock is stopped.

There are four main reasons for the lack of regularity in prosecution of violent sportspersons. Firstly, victims rarely report incidents to the police. This may be because the player feels that it is an expected part of participation and does not want to complain. Alternately, a revenge attack may be planned or the victim may have faith in the administering body to punish the perpetrator. ${ }^{63}$ The result of the lack of complaints is that the government cannot formulate an adequate policy for prosecution of sportspersons. Second, in order to prevent breaches of the peace, governments are more concerned about controlling crowd violence. Problems in the crowd result in threats to public safety and are prioritised over on-field violence which already has a punishment regime in place. ${ }^{64}$ Third, the prosecution can only go ahead with a case if there is a reasonable prospect of success. Public policy is that "properly conducted games and

\footnotetext{
59 Adam Epstein, Sports Law (1 $1^{\text {st }}$ ed, 2003) 91.

${ }^{60}$ Simon Gardiner, Alexandra Felix, Mark James, Roger Welch and John O’Leary, Sports Law (1 $1^{\text {st }}$ ed 1998$) 468$.

${ }^{61}$ No. 63280 (Hennipin Co. Minn.Dist,Ct. dismissed 12 Aug 1975), cited in Ellis Cashmore, Making Sense of Sports (3 ${ }^{\text {rd }}$ ed, 2000) 92.

${ }^{62}$ Ibid.

${ }^{63}$ Simon Gardiner, Alexandra Felix, Mark James, Roger Welch and John O’Leary, Sports Law (1 ${ }^{\text {st }}$ ed 1998$) 469$.

64 Ibid.
} 
sports are needed in the public interest.”65 However, the main problem with cases of sporting violence is the difficulty in proving intent. This is particularly the case where incidents occur during the flow of the game and ostensibly within the rules of the game. The other issue is that many involved in a trial, such as witnesses or jury members, are potentially biased against or in favour of the player. Fourth, the law is inconsistent in its approach to different sports. In the UK, football and rugby have a high level of conviction, whereas hockey does not. An offence as serious as manslaughter or murder is often not even considered when death occurs in the boxing ring.

\section{A Boxing and Violence}

Boxing is in a different category to other contact sports such as rugby or hockey. Boxers do not breach the rules of the match when they try to cause injury. Certain landmark cases in the UK such as $R v$ Coney ${ }^{66}$ contain obiter comments such that consent cannot make legal something that, on public policy grounds, should not be occurring at all. ${ }^{67}$ However, it is accepted that boxing is legal on the basis that the requirements provided in relevant legislation are adhered to. In Pallante v Stadiums Pty Ltd (No 1), ${ }^{68}$ it was suggested that if a fight goes beyond a test of skill and blows are intended to cause injury, it becomes illegal. ${ }^{69}$ Here again, the difficulty of proving intent is an issue.

Medical evidence proves that boxing causes immense health problems for competitors. In the twentieth century, over 500 men died as a result of injuries stemming from their involvement in boxing. ${ }^{70}$ The State recognises this, and many are in favour of a complete ban on boxing. Many consider it an activity that "honours violence and glorifies brutality."71 The much anticipated and publicised fight between Mike Tyson and Evander Holyfield in the MGM Grand, Las Vegas in 1997 provides a pertinent example.

\footnotetext{
${ }^{65}$ Hugh Brayne, Lincoln Sargeant and Carol Brayne, Could Boxing be Banned? A Legal and Epidemiological Perspective 1998< http://bmjjournals.com/cgi/content/full/316/7147/1813> at 12 October 2004 at [3], citing $R$ v Brown [1993] 2 All ER 116.

${ }^{66}$ (1892) 8 QBD 534.

${ }^{67}$ Hugh Brayne, Lincoln Sargeant and Carol Brayne, Could Boxing be Banned? A Legal and Epidemiological Perspective 1998 <http://bmjjournals.com/cgi/content/full/316/7147/1813> at 12 October 2004 at [7].

68 [1976] VR 33.

${ }^{69}$ Hugh Brayne, Lincoln Sargeant and Carol Brayne, Could Boxing be Banned? A Legal and Epidemiological Perspective 1998 $<$ http://bmjjournals.com/cgi/content/full/316/7147/1813> at 12 October 2004, [7].

${ }^{70}$ Douglas T Putnam, Controversies of the Sports World (1t ed, 1999) 179.

71 Ibid.
} 
Spectators were subjected to watching Tyson rip out a piece of Holyfield's ear with his teeth. When asked by angry and repulsed journalists world-wide why he behaved in this manner, Tyson stated that he "just snapped.”72 However, despite the presence of an adverse stance by many in the international community, boxing continues to be permitted as a sport in a significant number of countries. Boxing is renowned for its ability to provide opportunities for upward movement for many from disadvantaged backgrounds. This provides the State with a public policy reason to allow the sport to exist, ${ }^{73}$ but possibly not for its passive approach to regulation of the sport.

\section{B Assault in Contact Sports}

In Canadian hockey there exists an unwritten “code.” It applies when a member of a team is attacked during a game. The rest of his team will pursue the attacker on behalf of the injured. This is the norm in this sport. However, it does not always go unpunished. In an ice hockey match earlier this year, Todd Bertuzzi, a member of the Vancouver Canucks, punched his opponent Steve Moore rendering him unconscious. He then drove Moore head-first into the ice. Moore suffered two chipped vertebrae, a concussion and facial lacerations. Bertuzzi's act was one of violent retribution in retaliation against Moore’s earlier hit on Bertuzzi’s team-mate. He was suspended resulting in a loss of \$500,000 in pay, but was later charged with assault causing bodily harm. ${ }^{74}$ The result of this case is still pending. However, it is predicted that Bertuzzi's sentence will be significantly lower than a comparable sentence for a similar act committed in the wider community. This assumption is based on the sentences provided by the history of criminal convictions for assault on the sporting field. For example, Marty McSorley of the Boston Bruins sent an opponent sprawling across the ice after delivering an intentional hit with his stick. McSorley was found guilty of assault with a weapon but no charges would be recorded if he completed 18 months probation. ${ }^{75}$

\footnotetext{
${ }^{72}$ Douglas T Putnam, Controversies of the Sports World (1 $1^{\text {st }}$ ed, 1999) 179.

${ }^{73}$ National Committee on Violence, Violence: Directions for Australia. Part Three- The prevention and control of violence: conclusions and recommendations 1990 <http://www.aic.gov.au/publications/vda/vda-sec21.html> at 12 October 2004 at [10].

${ }^{74}$ Wikipedia, The Free Encyclopedia, 'Violence in Ice Hockey’ September 2004 http://en.wikipedia.org/wiki/Violence_in_ice_hockey> at 10 October 2004.

${ }^{75}$ CNNSI.com - NHL Hockey McSorley Found Guilty of Assault but Avoids Jail Time, October 2000

<http://sportsillustrated.cnn.com/hockey/nhl/news/2000/10/06/mcsorley_assault> at 10 October 2004.
} 
Australian Football League player, Leigh Matthews was convicted of assault and fined \$1,000 in 1985, after fracturing an opponent's jaw. This penalty was later reduced on appeal when Matthews was placed on a 12 month good behaviour bond. Despite this extreme act of rage, Matthews was considered to be a man of 'excellent character. ${ }^{76}$ However, Australians are apparently becoming less tolerant of violence in sport. Our perspective has changed so that we now see a player like Matthews who was once considered a "tough man" as an undisciplined handicap to the team. ${ }^{77}$ Hence, there is community support for the conviction of perpetrators on the sporting field.

The Australian Government has pointed out that the rule of law is not suspended when a player walks on the field. A player does not consent to assault by participating in sporting events. The National Committee on Violence recommended that sporting associations refer cases of criminal assault to law enforcement agencies for prosecution. ${ }^{78}$ This was a reaction to a series of violent incidents in sport in the 1980s. In the space of only four months in 1984, the Victorian police considered 10 incidents. These included one death, a player rendered comatose and another whose ear had been bitten off. ${ }^{79}$ In 1987 , Garry Anderson, a footballer, was prosecuted for biting off the top part of an opponent's index finger. ${ }^{80}$ In 1985, Leigh Matthews was the victim of Peter "Percy" Jones. After the event, Jones admitted that he hit him so hard that he hurt his own fist. However, he considered his violent act to be "just one of those things." The Victorian authorities thought otherwise and charged him with unlawful and malicious infliction of grievous bodily harm and assault occasioning bodily harm. ${ }^{81}$

\footnotetext{
${ }^{76}$ Rick Sarre, Leisure Time and the Law (1 $1^{\text {st }}$ ed, 1987) 18.

${ }^{77}$ Brien Wenn, Australian Institute of Criminology Violence Today. Violence in Sport 2004

$<$ http://www.aic.gov.au/publications/vt/vt4-text.html> at 10 October 2004.

${ }^{78}$ National Committee on Violence, Violence: Directions for Australia. Part Three- The prevention and control of violence: conclusions and recommendations 1990 <http://www.aic.gov.au/publications/vda/vda-sec21.html> at 12 October 2004.

${ }^{79}$ Daryl Adair and Wray Vamplew, Sport in Australian History $\left(1^{\text {st }} \mathrm{ed}, 1997\right) 132$.

80 Deborah Healey, Sport and the Law (1 ${ }^{\text {st }}$ ed, 1989) 98, citing Footballer sent for trial on finger-biting charges, Sydney Morning Herald 25 February 1987.

${ }^{81}$ Deborah Healey, Sport and the Law (1 $1^{\text {st }}$ ed, 1989) 97, citing Neil Mooney, VFL violence puts police on the field National Times 19 July 1985.
} 


\section{The Role of the Media}

Most games organisers believe there is a need for some degree of aggression in order for many sports to be effective as competitive spectacles. ${ }^{82}$ This is because "sports have moved beyond the mere playing of the game.” ${ }^{83}$ Television broadcasters provide playbacks of violent displays to home viewers. Radio has long been a means to bring the action to those who are unable to attend. Violent incidents are painted in sensationalist light in newspapers. At the game itself, displays of violence are emphasised by repeatedly being replayed on massive playback screens for the fans to view. On the one hand, violence is frowned upon by society. However, at the same time, many fans consider an attack or scuffle during a game to be the highlight of the event. If greater State intervention results in the elimination or reduction of violence, will anyone watch anymore? ${ }^{84}$

\section{Is STATE INTERVENTION ON THE SPORTING FIELD JUSTIFIED?}

State intervention is justified in its attempt to protect players from harm. Some would argue that the sporting bodies are able to do this. However, the State has to intervene in order to uphold the values of society and enforce punishments that will deter others from performing the same types of acts. ${ }^{85}$ It is hoped that the deterrence of violent actions will lessen the potential for crowd misbehaviour. Furthermore, as governments invest a significant amount of funding in the promotion and development of sport, there is a desire to protect the reputation of sport. In the sporting industry, a 'win at all costs' mentality has developed. ${ }^{86}$ Many professionals are more concerned with progression in their chosen sport to achieve wealth and prestige than with the maintenance of a level playing field. Therefore, the State needs to ensure that all sports are played in a socially acceptable way. This is usually done where the sporting administrative body does not provide a severe enough penalty.

\footnotetext{
${ }^{82}$ Ellis Cashmore, Making Sense of Sports ( $3^{\text {rd }}$ ed, 2000) 223.

${ }^{83}$ Robert C Berry and Glenn M Wong, Law and Business of the Sports Industries $\left(1^{\text {st }}\right.$ ed, 1993) 713.

${ }^{84}$ Jamie Fitzpatrick, Cultivating Todd Bertuzzi. 11 March 2004

$<$ http://proicehockey.about.com/cs/columnists/a/hockey_violence.htm> at 12 October 2004.

${ }^{85}$ Simon Gardiner, Alexandra Felix, Mark James, Roger Welch and John O’Leary, Sports Law (1 $1^{\text {st }}$ ed 1998$) 456$.

${ }^{86}$ Ibid 449.
} 
If an aim of the criminal law is to have some control over violence in sport, then it is not succeeding. ${ }^{87}$ While some may believe that the prosecution of high profile players sends a strong message to the public, many hold the opinion that the player is being treated unfairly. This is due to the fact that the State appears to choose to proceed with some cases over others. The rare player who is sent to prison is often treated as a hero when returning to his first match. This was so in the Scottish case of Ferguson $v$ Normand ${ }^{88}$ when 10 times the regular number of spectators attended Fergusson's return to the field.

The State holds the mistaken belief that making an example out of certain players will have an effect on the attitude of other sportspersons. Most players do not see a risk of prosecution as a real threat and are primarily concerned with winning. Thus, the only way for the criminal law to be more effective is to be more consistent and proactive. ${ }^{89}$ Furthermore, the longer that sport is treated as an unofficial mitigating factor by the courts, the longer the public will receive mixed messages. ${ }^{90}$ If the State created specific offences for sporting violence, held organisers and team officers liable to criminal charges such as aiding or counselling, and prohibited the broadcasting and display of violent acts then reform may be achieved. ${ }^{91}$ However, of great concern is the current trend in Australia to shy away from creating liability for personal injury in civil matters relating to recreational pursuits. ${ }^{92}$ The Commonwealth Government has even made special provision for those wishing to limit liability in relation to personal injuries or death resulting from the supply of recreational activities. ${ }^{93}$ This type of consideration in the realm of criminal law will almost certainly preclude the possibility of more frequent and consistent application of penalties for player violence on the sporting field.

\section{CONCLUSION: THE FUTURE FOR STATE REGULATION OF SPORT}

Today's sporting world is one of often ruthless competition where the stakes are extremely high. State intervention is necessary to ensure that the ethics and safety of all those associated with sport are

\footnotetext{
${ }^{87}$ Ibid 473.

${ }^{88}$ [1995] SCCR 770, cited in Simon Gardiner, Alexandra Felix, Mark James, Roger Welch and John O’Leary, Sports Law (1 ${ }^{\text {st }}$ ed, 1998) 473.

${ }^{89}$ Simon Gardiner, Alexandra Felix, Mark James, Roger Welch and John O’Leary, Sports Law (1 $1^{\text {st }}$ ed, 1998$) 473$.

${ }^{90}$ Ibid 472.

${ }^{91}$ John Barnes, Sports and the Law in Canada (3 ${ }^{\text {rd }}$ ed, 1996) 268.

${ }^{92}$ Civil Liability Act 2003 (Qld) ss 17-19.

${ }^{93}$ Trade Practices Act 1974 (Cth) s 68B.
} 
preserved. Furthermore, regulation must be applied consistently in order to ensure all sportspersons are treated fairly and equitably. Currently, this only appears to be the case where performance enhancing drugs are used by athletes.

There is a need for definitive policy in the realm of criminal law where State penalties are available for violent acts in contact sports. This is the only way players who break the rules of their chosen sport through an act causing serious injury to another player will be treated equally and fairly. The occasional "crackdown" on violent players, as seen in Australian football in the 1980s, is sending the wrong message to up and coming sportspersons. It allows a perpetuation of a "win at all costs" mind set, as there is only a small chance that criminal liability will result from poor behaviour on the sports field. Furthermore, penalties should extend to games organisers and coaches where their direct or indirect involvement with the athlete contributes to the committing of an abhorrent act. Media involvement in sport is also needs complimentary regulation, whereby any violent act committed in the sporting arena is prohibited from being broadcast. Of course, there are practicalities to consider. With the varying nature and requirements of each individual sport, a criminal law applying to all contact sports is conceivably impossible. The anomaly of boxing is one example of this difficulty. While it is accepted that boxing requires skill, one who clearly goes beyond the accepted level of violence in a match should be held to account, particularly if the act causes loss of life.

Is a more stringent approach to State control of sports a possibility? Today's society leans towards a conservative stance on many issues. If this way of thinking continues to evolve, one would think that it is unlikely that State leaders will be influenced to take more action regarding violence in sport. Political leaders are renowned for holding their own interests as paramount. For Communist countries, victorious performances on the international stage are seen as proof of their political system. ${ }^{94}$ It is in this socialist setting that sport is utilized as a social control to regulate activity in order to meet political goals. ${ }^{95}$ In common law countries, commercialism and economics are strong forces bearing down on political leaders.

\footnotetext{
${ }_{94}$ Martin Barry Vinokur, More Than a Game: Sports and Politics (1 ${ }^{\text {st }}$ ed, 1998) 133

95 Ibid.
} 
Conservative governments prevalent in democratic countries such as the USA and Australia are prepared to allow, and strive to advocate, commercialisation of sport in the name of economic growth. The current Coalition Government of Australia is advocating an economic policy characterised by deregulation. This drive towards privatisation provides a strong basis for a prediction that most of the future regulation of sport will continue to lie in the hands of independent sporting associations. 